\title{
RECENZJA MONOGRAFII ALEKSANDRA B. SZIROKORADA, BITWA O SYRIE. OD BABILONU DO ISIS, MOSKWA $2016^{2}$
}

W grupie najnowszych rosyjskojęzycznych wydawnictw, które ukazały się pod wspólnym tytułem Kroniki wspótczesności, moje ogromne zainteresowanie wywołała wydana w Moskwie w 2016 r. książka pod tytułem Bitwa o Syrię. Od Babilonu do ISIS (Битва за Сирию. От Вавилона до ИГИЛ). Јеј autorem jest rosyjski historyk, twórca licznych publikacji, Aleksander B. Szirokorad.

Sam tytuł był dla mnie o tyle interesujący, że w świetle nieomal równoległych wydarzeń wokół Ukrainy chciałem znaleźć dla siebie odpowiedzi na szersze pytanie o rolę, kształt i charakter działań wojennych oraz konfliktów (głównie tych z przełomu XX i XXI wieku) w ich irenologicznym aspekcie. Nie mogłem sobie odmówić przyjemności zapoznania się z jej treścią jeszcze z innego powodu - w Syrii bowiem w latach 1995-2008 pełnił służbę Polski Kontyngent Wojskowy w UNDOF (United Nations Disengagment Observer Force), a temat ten należy do obszaru moich badań naukowych.

Moje zainteresowanie książką wzbudził również fakt, że działania, którym poświęcona jest publikacja, prowadzone są w ważnym obszarze Bliskiego Wschodu. Ścierają się w nim interesy wielu państw - od światowych potęg do tych lokalnych graczy. Całość problemu wzmacniają np. wieloletnie dążenia Kurdów do utworzenia niezależnego państwa oraz ich odwieczny konflikt z Turcją. Tak więc „szachownica syryjska” ma geopolityczny wymiar.

Obszerna treść książki doprecyzowana podtytułem (Od Babilonu do ISIS) zawarta jest w 28 rozdziałach, przy czym można wydzielić trzy grupy tematów. Pierwsza grupa to tematy dotyczące historii (rozdziały od 1-9), obejmuje wydarzenia od starożytności do czasów, kiedy Syria została francuską kolonią - teoretycznie już w 1916 r. po serii rozmów dyplomatycznych Wielkiej Brytanii, Francji i Rosji, a praktycznie po zakończeniu pierwszej Wojny Światowej. Druga grupa tematów obejmuje wydarzenia do wojny w Libanie (rozdziały 10-22), czyli do 1982 r. W tej

\footnotetext{
${ }^{1}$ War Studies Academy; Poland.

2 А.Б. Широкорад, Битва за Сирию. От Вавилона до ИГИЛ, Москва 2016. [A.B.Szirokorad, Bitwa o Syrię. Od Babilonu do ISIS, wyd. „Wecze”, Moskwa 2016. s. 383]. ISBN 978-5-4444-4943-1.
} 
grupie są rozdziały poświęcone roli i miejscu Syrii w II Wojnie Światowej oraz w kolejnych wojnach (w tym sześciodniowej), a także roli floty radzieckiej w wojnie 1973 r. W treści rozdziałów możemy doszukać się pierwszych symptomów postępującego zacieśniania współpracy polityczno-wojskowej pomiędzy b. ZSRR i Syrią. Trzecia grupa tematyczna to współpraca radziecko-syryjska, a później rosyjsko-syryjska w końcu XX w. i w dwóch pierwszych dekadach XXI w. (rozdziały 23-28).

Rozdziały trzeciej grupy rzucają światło na dalszą ewolucję współpracy syryjsko rosyjskiej oraz rolę i znaczenie bazy morskiej w Tartusie ${ }^{3}$, również na jej rolę w wydarzeniach lat 20142016. Problem obecności okrętów Floty Wojennej b. ZSRR oraz Federacji Rosyjskiej autor przedstawia $\mathrm{w}$ rozdziale 24 . Rozpoczęła się ona od podpisania stosownego porozumienia rządowego w 1971 r. Do wybuchu konfliktu w Syrii port Tartus był wykorzystywany praktycznie jako punkt bazowania okrętów.

Tymczasem w sierpniu 2010 r. głównodowodzący Floty Wojennej Federacji Rosyjskiej, admirał W. S. Wysocki, w wywiadzie dla RIA Nowosti poinformował, że po 2012 r. Tartus będzie mógł przyjmować „ciężkie” okręty, tj. krążowniki i lotniskowce. I faktycznie, autor daje liczne przykłady powolnego, ale stałego powrotu okrętów Federacji Rosyjskiej do Syrii. Po 2012 r. przejścia okrętów, głównie desantowych, odbywały się w potocznym określeniu marynarzy jako „syryjski ekspres”. Autor nie wyjaśnia jednak, co transportowały, ani jakie działania podejmowały po $2014 \mathrm{r}$.

Ciekawy jest wątek narodzin ISIS (ИГИЛ - ИсламскоеГосударствоИракаи Леванта), jego funkcjonowania oraz roli Al-Kaidy w tym procesie i później - po wycofaniu poparcia dla parapaństwa islamskiego. Wskazane progowe aktywności tej terrorystycznej organizacji mogą budzić obawy o dalsze bezpieczeństwo w rejonie Bliskiego Wschodu.

Dwa ostatnie rozdziały odnoszą się do roli lotnictwa rosyjskiego w operacji w Syrii (s. 365375) oraz perspektyw wojny (s. 375-377). Niejako w konkluzji autor zakłada, że w tej sytuacji militarno-politycznej Syria, Irak i Iran są skazane na wspólne działania i raczej pomoc Rosji niż USA i Unii Europejskiej.

W kontekście tytułu treść książki jest rozciągnięta w czasie i głęboka w swojej zawartości, a zawiera w zasadzie dzieje konfliktów i wojen dość znaczącego obszaru Bliskiego Wschodu ziem, których nie można zaliczyć jednoznacznie do państwa syryjskiego. Uwzględniając, że państwo syryjskie w dzisiejszym kształcie i pod tą nazwą funkcjonuje oficjalnie od 1920 r., a faktycznie od 1946 r., tytuł publikacji staje się kwintesencją historii tego regionu.

Książka napisana jest prostym językiem, bez widocznych i jasno sformułowanych wniosków czy charakterystyk opisanych czasów i wydarzeń. Mój niedosyt budzi również brak jakichkolwiek map sytuacyjnych, co przy opisywaniu tak złożonej historii państwa (regionu) wydaje się zwykłą koniecznością.

\footnotetext{
3 W czasach rzymskich był znany jako Antaradus, a krzyżowcy używali nazwy Antartas lub Tortosa.
} 
Publikacja w zasadzie nie spełniła moich oczekiwań zapisanych w drugim akapicie tej recenzji, a sam opis historii zmagań wojennych na ziemi syryjskiej nie czyni tej pozycji wybitną. Również okładka książki w stosunku do jej treści jest myląca - syryjski T-55 nie wnosi żadnych skojarzeń, tak jak mapa w górnej części okładki.

Wymaga podkreślenia fakt włączenia do składu książki szerokiego zestawu oryginalnych zdjęć (28) - od starożytnych zabytków do fotografii ilustrujących skutki ostatnich walk. Bibliografia obejmuje 44 pozycje zwarte oraz 17 pozycji netograficznych, niestety wszystkie w wersji rosyjskojęzycznej. W bibliografii drukowanej doszukałem się trzech pozycji zagranicznych (wszystkie w tłumaczeniu na j. rosyjski), w tym Johna Betlera - Wielka strategia. Wrzesień 1939-czerwiec 1941, wydanej w 1959 r. przez Wydawnictwo Zagranicznej Literatury. Niestety w całej publikacji jest znikoma ilość przypisów.

Przebijające z książki rosyjskie spojrzenie autora na wydarzenia wokół Syrii (głównie wojny i konflikty) w perspektywie ponad 3000 lat będzie zapewne - mimo wszystkich wykazanych słabych stron - ciekawym (lecz związanym zapewne z subiektywnym spojrzeniem autora) źródłem porównawczych analiz dla politologów, historyków, wojskowych, studentów wielu specjalności (np. dziennikarstwa) i dużej rzeszy czytelników zainteresowanych wydarzeniami w świecie. $Z$ wielu powodów zachęcam jednak do zapoznania się z tą ciekawą publikacją rzucającą światło z innej perspektywy na wiele wydarzeń w szeroko pojmowanej strefie wojny domowej w Syrii i zwalczania państwa islamskiego.

Indywidualne wnioski i oceny książki każdy z czytelników wyrobi sobie po jej przestudiowaniu. Ja nie odnalazłem interesującego mnie kontekstu irenologicznego, tym niemniej polecam zainteresowanym. 